\title{
Studies on the Voges-Proskauer Reaction. I. Structure of Positive Substance in the Diacetyl Reaction ${ }^{1,2)}$
}

\author{
Tamio Nishimura, ${ }^{3 a}$ ) Shinzo Tanabe, ${ }^{3 b}$ ) Hiroshige Toku, ${ }^{3 a}$ ) \\ Tomoyuki Kono, ${ }^{3 b}$ ) YuzUru Sakabe, ${ }^{3 a}$ \\ and TAKEICHI SAKAGUCHI ${ }^{3 b}$ ) \\ Department of Chemistry, School of Hygienic Sciences, Kitasato \\ University $^{3 a}$ ) and Faculty of Pharmaceutical \\ Sciences, University of $C h i b a^{3 b)}$
}

(Received November 14, 1967)

\begin{abstract}
The structural limitation of positive compounds in the Voges-Proskauer Reaction was investigated with guanidines, ureas, thioureas, formamidine and formaldoxime, using the $\alpha$-naphthol alkaline and diacetyl solution.

Only guanidino derivatives showed positive reaction among compounds tested above. Strongly positive compounds were asym-1,1-dialkylguanidines.

Especially, 1,1-dimethylguanidine, 1-methyl-1-phenylguanidine and 1,1-pentamethyleneguanidine had the highest absorbance at $535 \mathrm{~m} \mu$.

Creatine which was usually used in this reaction, showed second higher absorbance. Monosubstituted guanidine gave always moderately positive reaction, and unsubstituted one was weakly positive.

sym-1,3-Dialkylguanidines such as 1,3-dimethylguanidine was negative, suggesting that a free amidino group $\left(\mathrm{H}_{2} \mathrm{~N}-\mathrm{C}-\right)$ would be necessary for the positive $\mathrm{V}-\mathrm{P}$ reaction. NH

This is further supported by the fact that tri-, tetra- and pentamethylguanidine also gave negative reaction.

8-Hydroxyquinoline could be used in place of $\alpha$-naphthol in this reaction.

Conditions for color development, stability of colored solution and the effect of $\mathrm{pH}$ on the wave length of $\lambda \max$ were studied.
\end{abstract}

Voges and Proskauer ${ }^{4)}$ reported in 1898 the production of an eosin-like coloration in glucose peptone cultures of certain organisms to which was added $10 \%$ potassium hydroxide. The reaction is generally referred to as the $\mathrm{V}-\mathrm{P}$ reaction and has been utilized to differentiate microorganisms. Harden ${ }^{5}$ showed that the coloration was due to the presence in the culture medium of acetylmethylcarbinol, which is a product of the growth of certain bacteria on sugars, and that acetylmethylcarbinol was oxidized to diacetyl in the course of the reaction. Subsequently, Harden and Norris ${ }^{6)}$ tested about seventy substances by the V-P test and found that arginine, agmatine, dicyandiamide, creatine and guanidinoacetic acid were positive in the V-P reaction.

They concluded that this diacetyl reaction for proteins was attributed to the presence in the protein of the group $\mathrm{NH}: \mathrm{C}\left(\mathrm{NH}_{2}\right) \mathrm{NHR}$. As the coloration is faint and indistinct, many attempts have been made to improve the test by increasing the rate of oxidation of

1) Presented at the 15th Annual Meeting of the Japan Society for Analytical Chemistry, Kyushu, October 1966.

2) Presented at the 20th Annual Meeting of the Chemical Society of Japan, Tokyo, April 1967.

3) Location: a) Shiba Shirogane Sanko-cho, Minato-ku, Tokyo; b) Yayoi-cho, Chiba-shi.

4) O. Voges and B. Proskauer, Z. Hyg. Infektionkrankh., 28, 20 (1898).

5) A. Harden, Proc. Roy. Soc. (London), Ser. B, 77, 424 (1906).

6) A. Harden and D. Norris, J. Physiol. (London), 42, 332 (1911). 
acetoin to diacetyl. ${ }^{7-9)} \mathrm{O}^{\prime} \mathrm{Meara}{ }^{10}$ ) could intensify the coloration by employing creatine in combination with $40 \% \mathrm{KOH}$ for the purpose of increasing the amount of the reacting guanidine group.

Barritt ${ }^{11)}$ led the V-P reaction to strikingly sensitive reaction by addition of $\alpha$-naphthol. Eggleton, ${ }^{12)}$ and Westerfeld ${ }^{13)}$ employed Barritt's method to determine acetoin, diacetyl and creatine. Mold, et al. ${ }^{14)}$ reported that the most intense coloration in the diacetyl reaction for some methyl substituted guanidines was given by 1,1-dimethylguanidine.

The authors found, however, that in all the preceding reports, little seemed to have been clarified about determining the range of functional groups concerning the reaction structure of $\mathrm{V}-\mathrm{P}$ positive substances.

In the present paper, we wish to give a full detail of the structural relation among various guanidinoderivatives and others.

\section{Experimental}

Reagents - All of the reagents used were of analytical grade, and $\alpha$-naphthol was recrystallized from EtOH and $\mathrm{H}_{2} \mathrm{O}$.

$a$-Naphthol: A $1 \%$ solution was prepared by dissolving $0.25 \mathrm{~g}$ of $\alpha$-naphthol in $25 \mathrm{ml}$ of an alkaline stock solution, which was prepared by dissolving $12 \mathrm{~g}$ of $\mathrm{NaOH}$ and $32 \mathrm{~g}$ of $\mathrm{Na}_{2} \mathrm{CO}_{3}$ in redistilled water and diluting to $200 \mathrm{ml}$.

This $\alpha$-naphthol solution was prepared before use.

8-Hydroxyquinoline ${ }^{15}$ ): A $0.1 \%$ solution was prepared shortly before use by dissolving $0.025 \mathrm{~g}$ of this reagent in $25 \mathrm{ml}$ of the alkaline stock solution described above.

8-Mercaptoquinoline: A $0.1 \%$ solution was prepared freshly each day by dissolving $0.025 \mathrm{~g}$ of this reagent in $25 \mathrm{ml}$ of the alkaline stock solution.

Diacetyl: A $0.05 \%$ aqueous solution was prepared by diluting 20 times the diacetyl stock solution $(1 \%)$ with water. This stock solution was kept in a refrigerator.

Procedure _-Each sample solution $(1 \mathrm{ml})$ was taken in a $10 \mathrm{ml}$ test tube with stopper.

One $\mathrm{ml}$ of $0.05 \%$ diacetyl solution and $2 \mathrm{ml}$ of $1 \% \alpha$-naphthol alkaline solution were introduced and diluted to $10 \mathrm{ml}$ with distilled water. The tubes were stored in dark after thorough shaking. After $15 \mathrm{~min}$ visible absorption spectra were determined to know absorption maxima of the colors given by various compounds by using a Hitachi recording spectrophotometer EPS-2.

The change in the color intensity relative to time at $\lambda$ max was then measured, $0.1 \% 8$-hydroxyquinoline and $0.1 \% 8$-mercaptoquinoline being also used instead of $1 \% \alpha$-naphthol. A mixture prepared by diluting $1 \mathrm{ml}$ of $0.05 \%$ diacetyl and $2 \mathrm{ml}$ of $1 \% \alpha$-naphthol alkaline solution to $10 \mathrm{ml}$ with distilled water was run as a blank.

For measurement of absorption spectra at different $\mathrm{pH}$ values, $5 \mathrm{ml}$ of a sample solution $(0.5 \mu \mathrm{mole} / \mathrm{ml})$, $5 \mathrm{ml}$ of $0.05 \%$ diacetyl solution, and $10 \mathrm{ml}$ of $1 \% \alpha$-naphthol solution were mixed and the mixture was diluted to $50 \mathrm{ml}$ with distilled water. After 10 min the solution was adjusted to a desired $\mathrm{pH}$ by adding $1 \mathrm{~N} \mathrm{HCl}$ and its spectrum was determined on the photometer.

Material - The following material were prepared according to the methods described in the literature: 1-methyl-2-thiourea, ${ }^{16)} \mathrm{mp} 119-121^{\circ} ; 1,1,3$-trimethyl-2-thiourea, ${ }^{16)} \mathrm{mp}$ 77-78 $; 1,1,3,3$-tetramethyl-2thiourea, ${ }^{17)} \mathrm{mp} 76-77.5^{\circ} ; 2,3$-dimethyl-2-thiopseudourea hydroiodide, ${ }^{18 a)} \mathrm{mp} 133-134^{\circ} ; 1,2,3$-trimethyl-2thiopseudourea hydroiodide, ${ }^{186)} \mathrm{mp} 208-210^{\circ} ; 1$-methylguanidine sulfate, ${ }^{19)} \mathrm{mp} 237.5^{\circ} ; 1$-phenylguanidine

7) F.D. West, Am. J. Pwb. Hyg., 19, 227 (1909).

8) R.H. Bedford, J. Bacteriol., 18, 93 (1929).

9) C.H. Werkman, J. Bacteriol., 20, 121 (1930).

10) R.A.Q. O'Meara, J. Pathol. Bacteriol., 34, 401 (1931).

11) M.M. Barritt, J. Pathol. Bacteriol., 42, 441 (1936).

12) P. Eggleton, S.R. Elsđen, and N. Gaugh, Biochem. J., 37, 526 (1943).

13) W.W. Westerfeld, J. Biol. Chem., 161, 495 (1945).

14) J.D. Mold, J.M. Ladino, and E.J. Schantz, J.Am. Chem. Soc., 75, 6321 (1953).

15) K. Niijima and T. Okuyama, Seikagaku, 35, 52 (1963).

16) M.L. Moore and F.S. Crossley, Org. Syn., Col. Vol. 3, 617.

17) M.M. Delepine, Bull. Soc. Chim. France, 7, 989 (1910).

18) a) M. Schenk, Z. Physiol. Chem., 77, 349 (1912); b) Idem, ibid., 77, 365 (1929).

19) R. Phillips and H.T. Clarke, J. Am. Chem. Soc., 45, 1775 (1923). 


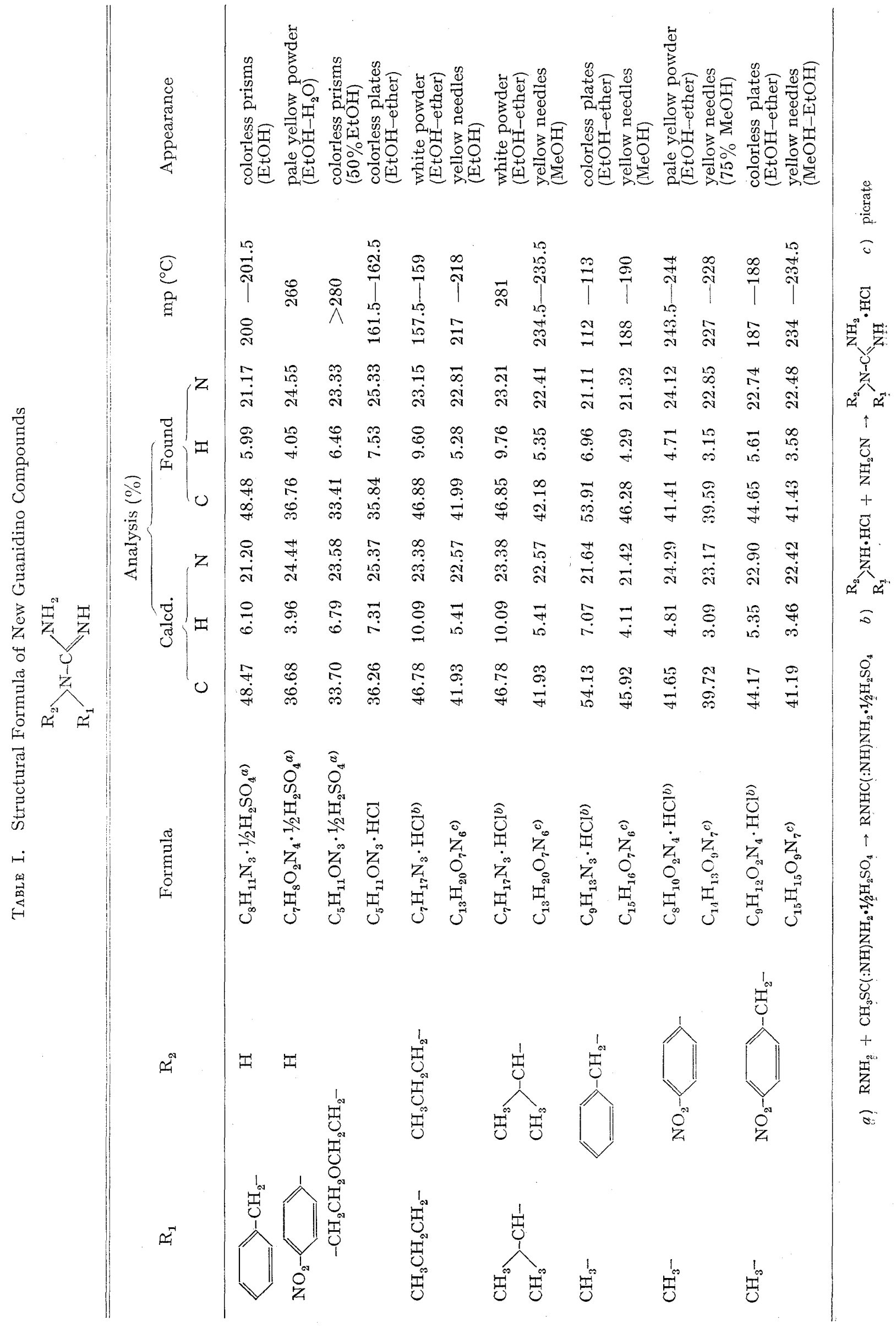


nitrate, ${ }^{20)} \mathrm{mp} 120-121^{\circ} ; 1-n$-butylguanidine sulfate, ${ }^{21)} \mathrm{mp} 214^{\circ} ; 1,1$-dimethylguanidine sulfate, ${ }^{19)} \mathrm{mp} 291^{\circ}$, hydrochloride, mp $140-148^{\circ} ; 1,1$-pentamethyleneguanidine sulfate, ${ }^{22)} \mathrm{mp} 286^{\circ}$ (decomp.), hydrochloride, ${ }^{23)}$ $\mathrm{mp} 183-184^{\circ} ; 1,1$-anhydrobis $\left(2^{\prime}\right.$-hydroxyethyl) biguanide hydrochloride, ${ }^{23)} \mathrm{mp} 188.5-191^{\circ} ; 1,1$-dimethylbiguanide hydrochloride, ${ }^{24)} \mathrm{mp} 220-221.5^{\circ} ; 1,3$-dimethylguanidine hydroiodide, ${ }^{25)} \mathrm{mp} 92-96^{\circ}$, picrate, $\mathrm{mp} 177-177.5^{\circ} ; 1,2,3$-trimethylguanidine hydroiodide, ${ }^{25)} \mathrm{mp}>305^{\circ} ; 1,1,3$-trimethylguanidine hydroiodide ${ }^{25)}$ $\mathrm{mp} 200-201^{\circ} ; 1,1,2,3$-tetramethylguanidine hydroiodide, ${ }^{25)} \mathrm{mp} 106-110^{\circ}$, picrate, mp $160-161.5^{\circ} ; 1,1,2,-$ 3,3-pentamethylguanidine hydroiodide, ${ }^{25)} \mathrm{mp} 118.5-119.5^{\circ}$, picrate, $\mathrm{mp} 162-163^{\circ} ; 1$,1-diethylguanidine hydrochloride, ${ }^{26,27)} \mathrm{mp} 148-150^{\circ}$, picrate, $\mathrm{mp} 220^{\circ} ; 1,1$-di-n-butylguanidine hydrochloride, $\left.{ }^{27}\right) \mathrm{mp} 104-$ $105^{\circ}$, picrate, mp $153-155^{\circ}$; 1-methyl-2-phenylguanidine hydrochloride, ${ }^{28)} \mathrm{mp} 213-213.5$, picrate, mp

TABLE II. Absorption Maxima of Colored Solution produced from Various Nitrogen Compounds

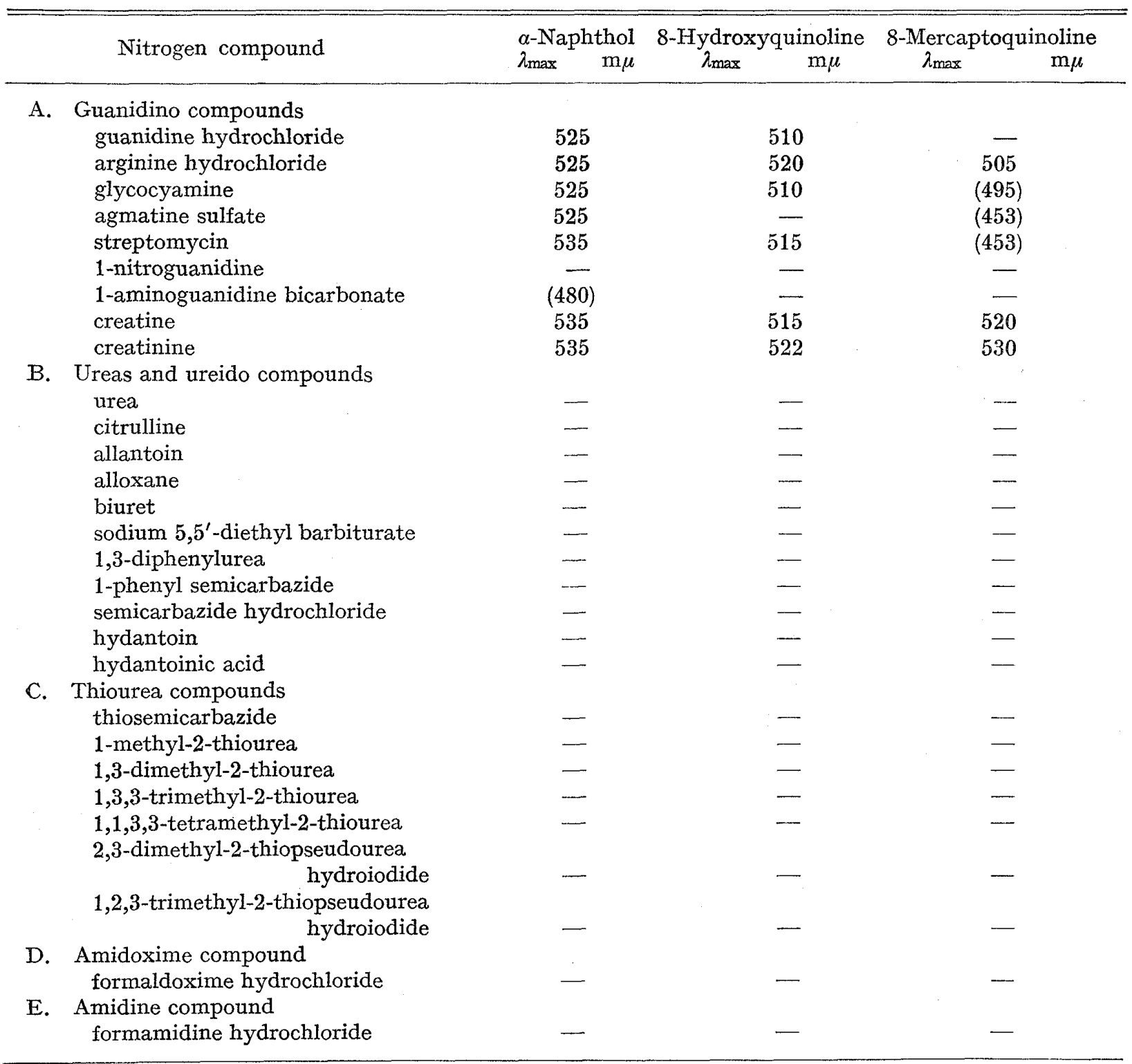

20) G.B.L. Smith, J. Am. Chem. Soc., 51, 477 (1929).

21) H. King and I.M. Tomkin, J. Chem. Soc., 1946, 1065.

22) W.F. Cockburn and R.A.B. Bannard, Can. J. Chem., 35, 1285 (1957) [C.A., 52, 10076 (1958)].

23) S.L. Shapiro, V.A. Parrino, and L. Freedman, J. Am. Chem. Soc., 81, 3770 (1959).

24) K. Sugino, Yuki Gosei Kagaku Kyokaishi, 13, 307 (1955).

25) S.J. Angyal and W.K. Warburton, J. Chem. Soc., 1951, 2493.

26) H. Lecher and G. Demmler, Z. Physiol. Chem., 167, 172 (1927).

27) E.J. Cragoe, Jr., Belg. Patent, 639386 (1964) [C.A., 62, 14702 (1965)].

28) C.E. Braun, J. Am. Chem. Soc., 55, 1282 (1933). 


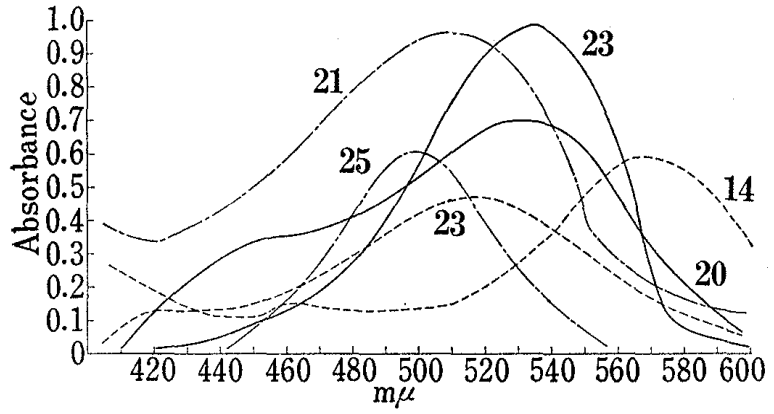

Fig. 1. Absorption Spectra of Colors produced by Positive Compounds

$-\alpha$-naphthol-diacetyl

8-hydroxyquinoline-diacetyl

- - - 8-mercaptoquinoline-diacetyl

concentration $(\mu \mathrm{mole} / \mathrm{ml})$ :

Measured after $30 \mathrm{~min}$
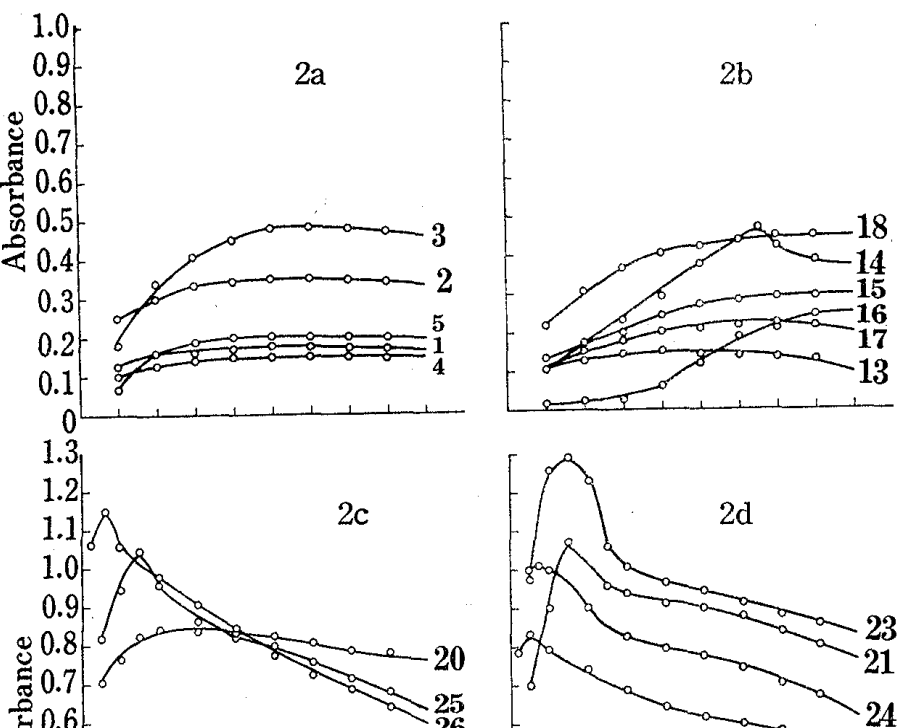

$2 \mathrm{~d}$

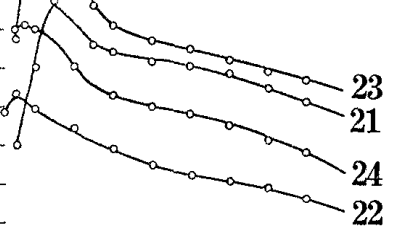

0.5
0.4

0.4
0.3

0.2

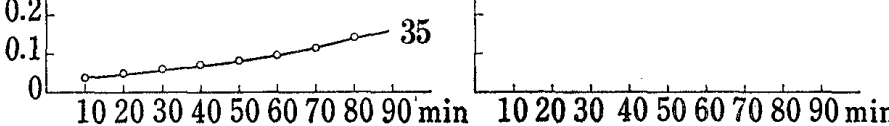

Fig. 2. Effect of Standing Time on Absorbance at $\lambda_{\max }$ $(\alpha-N a p h t h o l-d i a c e t y 1)$

$\mathrm{a}, \mathrm{b})$ concentration $(\mu \mathrm{mole} / \mathrm{ml}): 0.1 \mathrm{c}, \mathrm{d})$ concentration $(\mu \mathrm{mole} / \mathrm{ml}): 0.05$ The numbers in the figure indicate the compound number.

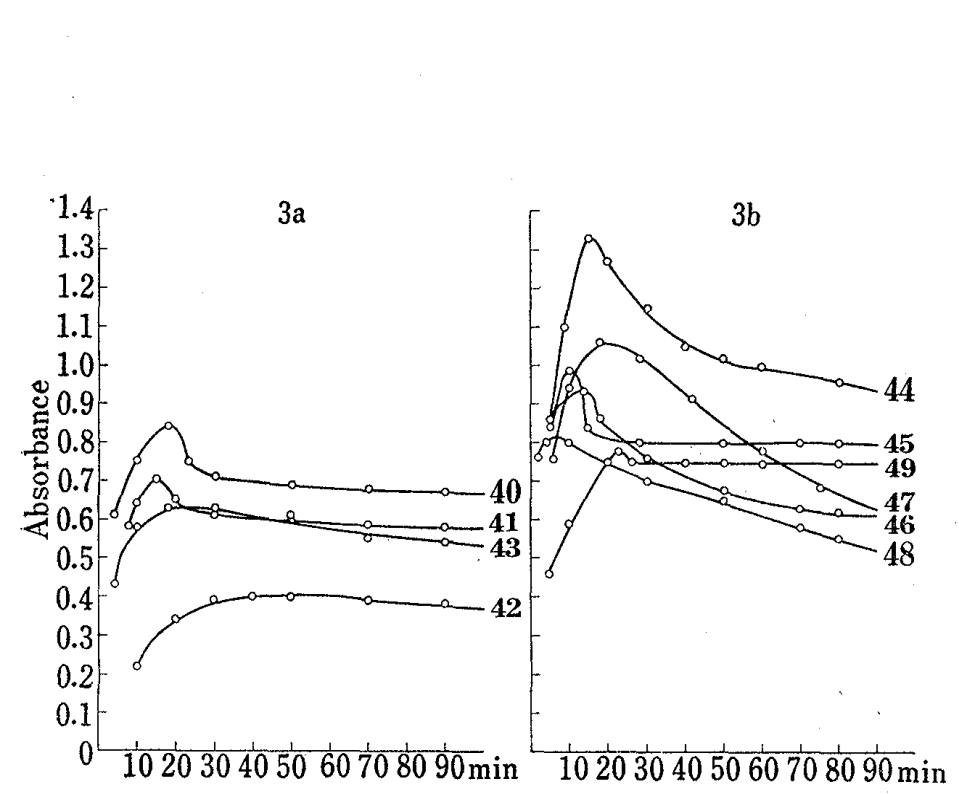

Fig. 3. Effect of Standing Time on Absorbance at $\lambda_{\max }$ $(\alpha-$ Naphthol-diacetyl)

concentration $(\mu \mathrm{mole} / \mathrm{ml}): 0.05$

The numbers in the figure indicate the compound number.

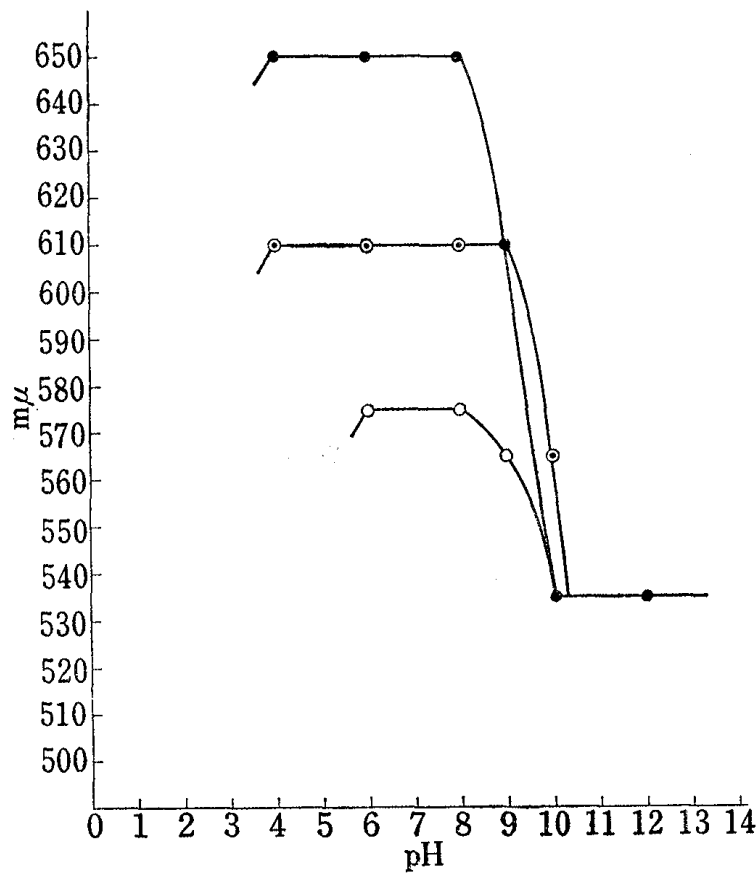

Fig. 4. Effect of $\mathrm{pH}$ on Wave Length of Absorption Maximum

creatine (20)
1,1-dimethylguanidine sulfate (22)
1,1-pentamethyleneguanidine sulfate (24) 


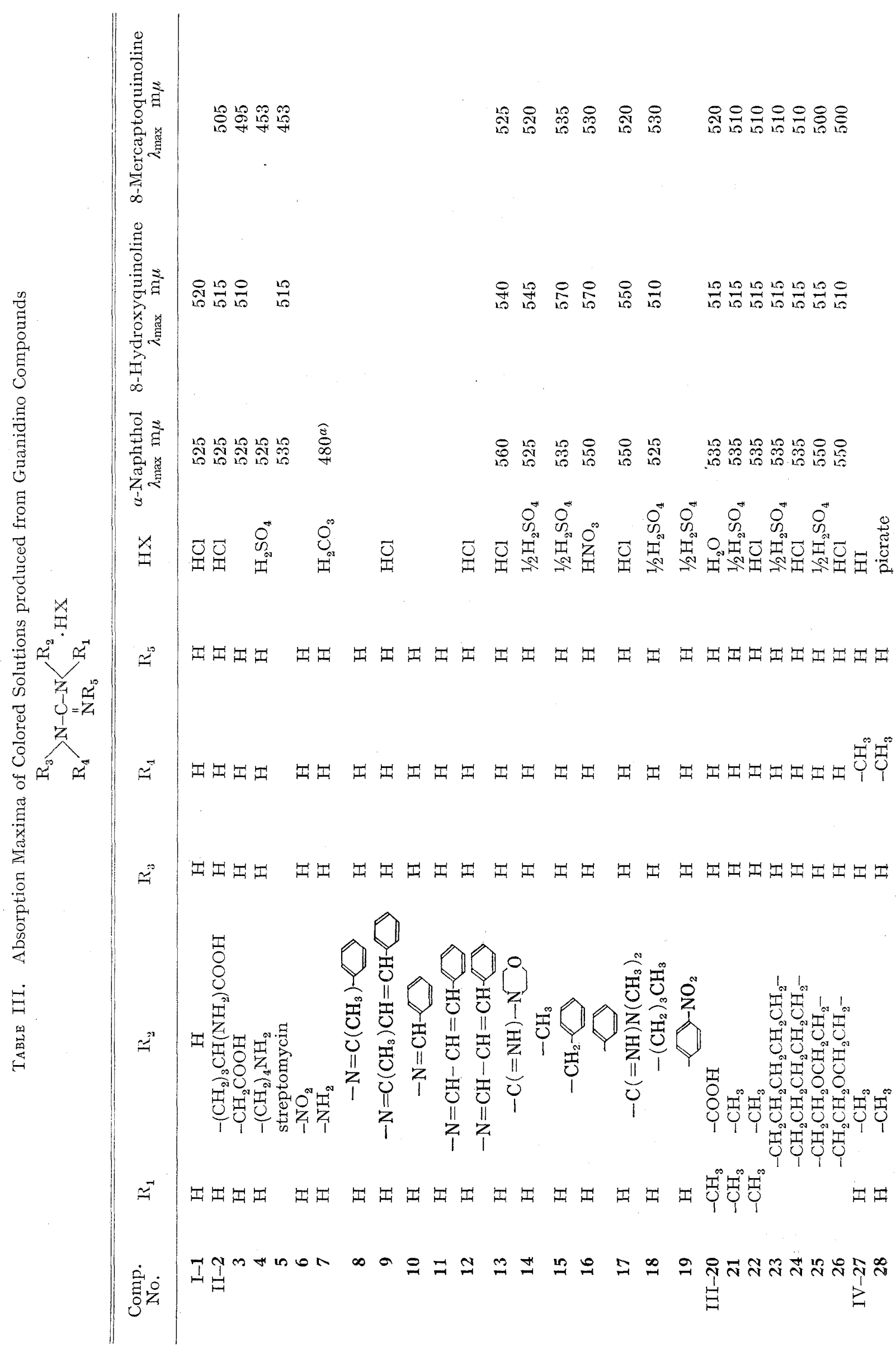


藏

กิ้

窝

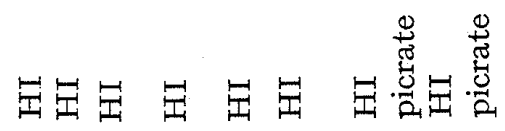

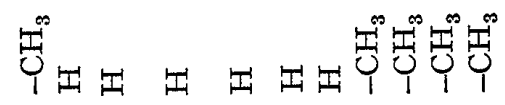

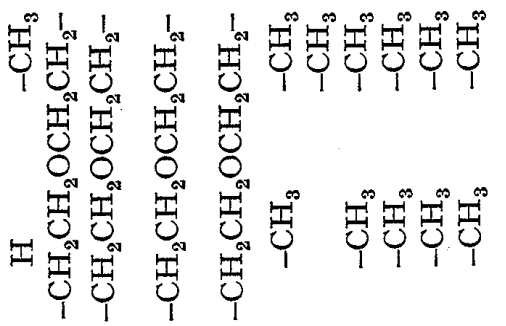

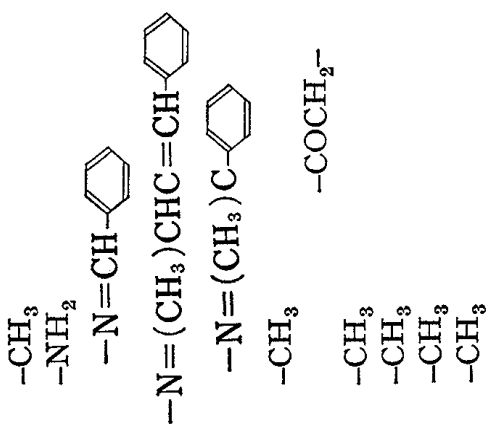

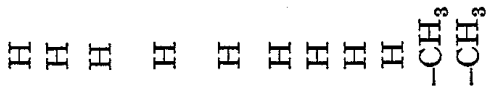

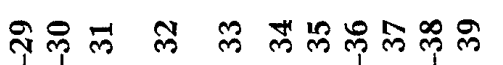

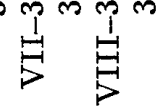

$224.5-225^{\circ} ; 1$,1-dibenzylguanidine hydrochloride, ${ }^{29)} \mathrm{mp} 191-$ $192^{\circ}$, picrate, $174-174.5^{\circ} ; 1,1$-tetramethyleneguanidine sulfate, ${ }^{30}$ ) $\mathrm{mp}>305^{\circ}$, picrate, ${ }^{31)} \mathrm{mp} 214-215^{\circ}$. Synthesis of nine amidinohydrazones $(8-12,30-33)$ will be published elsewhere.

Eight new guanidino compounds synthesized by reacting the corresponding secondary amines with 2-methyl-2-thiopseudourea of cyanamide are summarized in Table $\mathrm{I}$.

\section{Results}

Results of the test conducted at a concentration of $0.1 \mathrm{~mm}$ of substances, using $1 \% a$-naphthol alkali, $0.1 \%$ 8-hydroxyquinoline and $0.1 \%$ 8-mercaptoquinoline, with $0.05 \%$ diacetyl solution, and the wave lengths of absorption maxima of the colored solution produced from various compounds are summarized in Table II $(\mathrm{A}, \mathrm{B}$, C, D, E).

The compounds tested are classified into five groups; $\mathrm{A}$ (guanidines), $\mathrm{B}$ (ureas), $\mathrm{C}$ (thioureas), $\mathrm{D}$ (formaldoxime), and $\mathrm{E}$ (formamidine).

From the results of Table II, we found that only guanidino compounds showed positive reaction. Therefore, we have classified further the guanidino compounds to the eight classes as listed in Chart 1.<smiles>N=C(N)N</smiles>

I<smiles>[R2]NC(=N)N([R])[R]</smiles>

$\mathbb{N}$<smiles>[R]N([R2])C([R16])([Y16])[Y]</smiles>

VII<smiles>[R]N([R])C(=N)N</smiles>

II<smiles>[R][NH+]=C([R2])N([R])[R]</smiles>

$\mathrm{V}$<smiles>[R16]C(N([R])[R2])=[N+]([R2])[R]</smiles>

VIII<smiles>[R]NC(=N)N([R2])[R2]</smiles>

III<smiles>[R2]NC(=N)N([R])[R]</smiles>

And we tested 39 compounds including unsubstituted (I-1), monosubstituted (II-2-19), disubstituted (II-20-25, IV-27-28), trisubstituted (V-29, VI-3035), tetrasubstituted (VII-36, 37), and pentasubstituted (VIII-38, 39) as described in Table III.

29) K.J.M. Andrews, N. Anand, A.R. Todd, and A. Tophan, $J$. Chem. Soc., 1949, 2490 [C.A., 44, 2931 (1950)].

30) J.H. Short, U. Biermacher, D.A. Dunnigan, and T.D. Leth, J. Med. Chem., 6, 280 (1963).

31) F.L. Scott, D.G. O'Donovan, and J. Reilly, J. Am. Chem. Soc., 75, 4053 (1953). 
TABLE IV. Color Intensity of V-P Reaction Positive Compounds

\begin{tabular}{|c|c|c|c|}
\hline $\begin{array}{l}\text { Comp. } \\
\text { No. }\end{array}$ & $\begin{array}{c}\alpha \text {-Naphthol } \\
\left(\varepsilon^{\prime}\right)\end{array}$ & $\begin{array}{l}\text { 8-Hydroxyquinoline } \\
\left(\varepsilon^{\prime}\right)\end{array}$ & $\begin{array}{c}\text { 8-Mercaptoquinoline } \\
\left(\varepsilon^{\prime}\right)\end{array}$ \\
\hline$I-1$ & $1.79 \times 10^{3}$ & $2.40 \times 10^{2}$ & \\
\hline II -2 & $3.65 \times 10^{3}$ & $6.20 \times 10^{2}$ & $2.60 \times 10^{2}$ \\
\hline 3 & $5.01 \times 10^{3}$ & $5.10 \times 10^{2}$ & $2.80 \times 10^{2}$ \\
\hline 4 & $1.63 \times 10^{3}$ & & $1.90 \times 10^{2}$ \\
\hline 5 & $5.20 \times 10^{3}$ & $1.90 \times 10^{2}$ & $0.90 \times 10^{2}$ \\
\hline 13 & $1.57 \times 10^{3}$ & $4.20 \times 10^{2}$ & $0.20 \times 10^{2}$ \\
\hline 14 & $4.84 \times 10^{3}$ & $1.45 \times 10^{2}$ & $0.13 \times 10^{2}$ \\
\hline 15 & $2.97 \times 10^{3}$ & $2.90 \times 10^{2}$ & $5.90 \times 10^{2}$ \\
\hline 16 & $2.77 \times 10^{3}$ & $2.50 \times 10^{2}$ & $0.53 \times 10^{2}$ \\
\hline 17 & $2.21 \times 10^{3}$ & $4.70 \times 10^{2}$ & $0.28 \times 10^{2}$ \\
\hline 18 & $2.36 \times 10^{3}$ & $2.05 \times 10^{2}$ & $0.48 \times 10^{2}$ \\
\hline III-20 & $\begin{array}{l}1.68 \times 10^{4} \\
\left(2.84 \times 10^{3}\right)^{a)}\end{array}$ & $1.60 \times 10^{3}$ & $7.65 \times 10^{2}$ \\
\hline 21 & $\begin{array}{c}2.24 \times 10^{4} \\
\left(4.50 \times 10^{3}\right)\end{array}$ & $1.70 \times 10^{3}$ & $5.50 \times 10^{2}$ \\
\hline $22^{b)}$ & $1.68 \times 10^{4}$ & $2.10 \times 10^{3}$ & $4.70 \times 10^{2}$ \\
\hline 23 & $\begin{array}{r}2.54 \times 10^{4} \\
\left(6.60 \times 10^{3}\right)\end{array}$ & $2.40 \times 10^{3}$ & $7.25 \times 10^{2}$ \\
\hline 24 & $2.10 \times 10^{4}$ & $2.14 \times 10^{3}$ & $6.35 \times 10^{2}$ \\
\hline 25 & $\begin{array}{c}2.10 \times 10^{4} \\
\left(4.30 \times 10^{3}\right)\end{array}$ & $1.61 \times 10^{3}$ & $3.15 \times 10^{2}$ \\
\hline 26 & $2.30 \times 10^{4}$ & $2.44 \times 10^{3}$ & $5.09 \times 10^{2}$ \\
\hline VI-35 & $3.04 \times 10^{3}$ & $4.20 \times 10^{2}$ & $0.25 \times 10^{2}$ \\
\hline II-7 & $0.36 \times 10^{2}$ & & \\
\hline
\end{tabular}

All data are measured at maximum absorptivity.

a) $0.1 \% \alpha$-naphthol

b) This material is considered to be impure, as judged from the molar absorptivity, melting point and elemental analyses.

TABLE V. Relationship of Chemical Structure with Color Intensity<smiles>[R1]N([R1])C(=N)N</smiles>

\begin{tabular}{|c|c|c|c|c|c|}
\hline Comp. No. & $\mathrm{R}_{1}$ & $\mathrm{R}_{2}$ & $\mathrm{HX}$ & $\lambda_{\max } \mathrm{m} \mu$ & $\varepsilon_{\max }^{\prime a)}\left(\times 10^{4}\right)$ \\
\hline 20 & $\mathrm{CH}_{3}-$ & $-\mathrm{CH}_{2} \mathrm{COOH}$ & $\mathrm{H}_{2} \mathrm{O}$ & 535 & $1.68(0.01)$ \\
\hline 21 & $\mathrm{CH}_{3-}$ & $\mathrm{CH}_{3}-$ & $1 / 2 \mathrm{H}_{2} \mathrm{SO}_{4}$ & 535 & $2.22(0.04)$ \\
\hline 40 & $\mathrm{C}_{2} \mathrm{H}_{5}-$ & $\mathrm{C}_{2} \mathrm{H}_{5}$ & $\mathrm{HCl}$ & 525 & $1.67(0.00)$ \\
\hline 41 & $n-\mathrm{C}_{3} \mathrm{H}_{7}-$ & $n-\mathrm{C}_{3} \mathrm{H}_{7}-$ & $\mathrm{HCl}$ & 525 & $1.41(0.02)$ \\
\hline 42 & iso- $\mathrm{C}_{3} \mathrm{H}_{7}-$ & iso- $\mathrm{C}_{3} \mathrm{H}_{7}-$ & $\mathrm{HCl}$ & 525 & $0.80(0.00)$ \\
\hline 43 & $n-\mathrm{C}_{4} \mathrm{H}_{9}-$ & $n-\mathrm{C}_{4} \mathrm{H}_{9}-$ & $\mathrm{HCl}$ & 525 & $1.25(0.00)$ \\
\hline 44 & $\mathrm{CH}_{3}-\cdots$ & $\mathrm{C}_{6} \mathrm{H}_{5}-$ & $\mathrm{HCl}$ & 540 & $2.70(0.00)$ \\
\hline 45 & $\mathrm{CH}_{3}-$ & $\mathrm{C}_{6} \mathrm{H}_{5} \mathrm{CH}_{2}-$ & $\mathrm{HCl}$ & 535 & $1.99(0.00)$ \\
\hline 46 & $\mathrm{C}_{6} \mathrm{H}_{5} \mathrm{CH}_{2}-$ & $\mathrm{C}_{6} \mathrm{H}_{5} \mathrm{CH}_{2}-$ & $\mathrm{HCl}$ & 540 & $1.85(0.00)$ \\
\hline 47 & $\mathrm{CH}_{3}-$ & $p-\mathrm{NO}_{2}-\mathrm{C}_{6} \mathrm{H}_{4}-$ & $\mathrm{HCl}$ & 590 & $2.15(0.00)$ \\
\hline 48 & $\mathrm{CH}_{3}-$ & $p-\mathrm{NO}_{2}-\mathrm{C}_{6} \mathrm{H}_{4} \mathrm{CH}_{2^{-}}$ & $\mathrm{HCl}$ & 535 & $1.63(0.00)$ \\
\hline 49 & \multicolumn{2}{|c|}{$-\left(\mathrm{CH}_{2}\right)_{4}-$} & $1 / 2 \mathrm{H}_{2} \mathrm{SO}_{4}$ & 535 & $1.55(0.00)$ \\
\hline 23 & \multicolumn{2}{|c|}{$-\left(\mathrm{CH}_{2}\right)_{5}-$} & $1 / 2 \mathrm{H}_{2} \mathrm{SO}_{4}$ & 535 & $2.55(0.10)$ \\
\hline 25 & \multicolumn{2}{|c|}{$-\mathrm{CH}_{2} \mathrm{CH}_{2} \mathrm{OCH}_{2} \mathrm{CH}_{2}-$} & $1 / 2 \mathrm{H}_{2} \mathrm{SO}_{4}$ & 550 & $2.30(0.00)$ \\
\hline
\end{tabular}

a) the mean of two independent experiments

The figures in parentheses represent the difference between the two experimental values. 
Color intensity of eleven positive representative compounds are shown in Table IV and relationships of chemical structure with the color intensity of 1,1-dialkylguanidines $(\mathbf{2 1}, \mathbf{4 0}$ 43), 1,1-alkyleneguanidines $(\mathbf{2 3}, \mathbf{4 9})$, and 1-methyl-1-benzylguanidines $(\mathbf{4 5}, \mathbf{4 8})$ are shown in Table V.

The curves of absorption spectra of the colors produced by the main, positive compounds are shown in Fig. 1.

Effect of standing time on absorbance at $\lambda_{\max }$, using $\alpha$-naphthol and diacetyl is shown in Fig. 2a, 2b, 2c, and in Fig. 3a, 3b.

Finally, the effect of $\mathrm{pH}$ on wave lengths of absorption maximum of creatine, 1,1-dimethylguanidine sulfate and 1,1-pentamethyleneguanidine sulfate is shown in Fig. 4.

\section{Discussion and Conclusion}

\section{Nature of Functional Group}

As demonstrated in Table III, only unsubstituted, mono-, and asym-1,1-disubstituted guanidines gave the positive reaction with the exception of 1-nitro-(II-6), 1-amino-(II-7, VI-30), substituted 1-amino-(II-8-12, VI-31-33) and 1- $p$-nitrophenyl-(II-19) guanidine. As indicated in Table IV and Table $\mathrm{V}$ the compounds which gave the most intense coloration were asym-1,1-disubstituted guanidines (III-groups in Table IV and $\mathbf{4 0 - 4 9}$ compounds in Table V).

On the other hand, it was a very important evidence that 1,3-dimethylguanidine was negative, suggesting that a free amidino group would be necessary for the positive $\mathrm{V}-\mathrm{P}$ reaction.

This is further supported by the fact that tri-(VI-34, V-29), tetra-(VII-36, 37), and penta-(VIII-38, 39)methylguanidines gave also negative reaction (Table III). From these results it was concluded that in the guanidino compounds, the presence of a free amidino group whose carbon is attached to an amino-nitrogen, should be necessary for the positive $\mathrm{V}-\mathrm{P}$ reaction.

In the unsubstituted formamidine ( $\mathrm{E}$ in Table $\mathrm{II}$ ), however, this reaction was negative, because it has hydrogen directly on the carbon of amidino group. ments.

For the exact reason of this structural relations would be necessary more detailed experi-

\section{2. $\lambda_{\max }$ of Positive Substances}

Unsubstituted and mono substituted guanidines, if positive, gave the colors having absorption maximum at $525-535 \mathrm{~m} \mu$ when $\alpha$-naphthol was used.

Also asym-1,1-dialkylguanidines (20, 21, 40-43), asym-1,1-alkyleneguanidines (23, 49), and 1-methyl-1-benzylguanidines $(\mathbf{4 5}, \mathbf{4 8})$ gave the color, having almost the same $\lambda_{\max }$ at $525-535 \mathrm{~m} \mu$.

The $\lambda_{\max }$ was slightly longer $(540-550 \mathrm{~m} \mu)$ in 1-methyl-1-phenyl-(44), 1,1-dibenzyl-(46), and 1,1-anhydrobis (2'-hydroxyethyl)-(25) guanidines, while guanidine derivatives having 1,1-anhydrobis (2'-hydroxyethyl) amidino-(13), 1,1-dimethylamidino-(17), and phenyl-(16) substituted ion gave the colors having absorption maxima at $550-560 \mathrm{~m} \mu$.

\section{Comparison of the Color Intensities with the Length of Alkyl Side Chain in 1,1-Dialkyl- guanidines (21, 40-43) (Table V)}

It was revealed that the intensity was highest with shortest side chain compound, 1,1dimethylguanidine, and decreased with diethyl, di-n-propyl and di-n-butyl derivatives in the order of longer length of side chain.

And di-isopropyl derivatives (42) gave the color of lower intensity than di-n-propyl derivative (41). As is obvious from the comparison of 1,1-dimethylguanidine with methyl- 
phenylguanidine, replacement of phenyl group for a methyl group of the former compound resulted in the marked increase 10 times in the intensity of color produced.

Benzyl substituted derivative (45) gave the color of less intensity than that produced by phenyl substituted guanidine (44). Dibenzylguanidine (46) produced the color of almost the same intensity as that given by monobenzyl derivative (45).

\section{Comparison of the Color Intensities among 1,1-Dialkyleneguanidines}

Pentamethylene derivatives (23) gave the color of higher intensity than tetramethyleneguanidine (49) containing less carbon atoms.

This result is of a marked difference from that obtained in 1,1-dialkylguanidines.

\section{Introduction of Nitro Group into the Benzene Ring of V-P Positive Guanidine Derivatives}

Introduction of a nitro group into the benzene ring showed the effect of reducing the color intensity as revealed by the comparison of 1-methyl-1-phenylguanidine with 1-methyl1-p-nitrophenylguanidine, and of 1-methyl-1-benzyl-with 1-methyl-1-p-nitrobenzylguanidine (Table IV).

In accordance with finding this, moderately V-P positive 1-phenylguanidine (16) was converted into an entirely negative 1-p-nitrophenylguanidine (19) (Table III, IV).

\section{Introduction of $-\mathrm{N}=\mathrm{C}<$ Group to the Aminonitrogen of the Guanidino Compounds}

Introduction of this group either to the aminonitrogen of guanidine directly (8-12 in Table III) or to the same nitrogen of monosubstituted guanidines (31-33 in Table III) showed an entirely negative $\mathrm{V}-\mathrm{P}$ reaction.

Also introduction of amino and nitro group directly to the aminonitrogen of guanidine led to the negative results.

\section{The Applicability of 8-Hydroxy- and 8-Mercaptoquinoline for $a$-Naphthol in V-P Reaction}

As it was impossible to prepare $1 \%$ solution of 8 -hydroxy- and 8-mercaptoquinoline respectively, color intensities given by $0.1 \%$ solutions of these reagents were compared with several 1,1-disubstituted guanidines $(\mathbf{2 0}, \mathbf{2 1}, \mathbf{2 3}, \mathbf{2 5})$. As a result, it was found that $\alpha$-naphthol, 8-hydroxy- and 8-mercaptoquinoline give the colors having the decreasing intensity and with the shift of $\lambda_{\max }$ to shorter wave lengths in the order named (Table III).

\section{Conditions for Color Development and Color Stability}

When $\alpha$-naphthol was used, the intensities of colors produced by unsubstituted and mono-substituted guanidines $(\mathbf{1}-\mathbf{5}, \mathbf{1 3}-\mathbf{1 8})$ reached to maxima in 50-70 min except for monophenylsubstituted one and slowly decreased except for monomethyl one (Fig. 2a, 2b).

In the case of creatine (20), however, the rapid decrease was not observed. Creatinine (35) developed the color very slowly (Fig. 2c). This might be ascribed to the conversion of creatinine to creatine in alkaline medium. As is obvious from Fig. $3 \mathrm{a}, 3 \mathrm{~b}$, the color intensities produced by di- $n$-butyl-(43), and di-isopropyl-(42) guanidines reached to a maximum in $20-40$ min and gradually decreased thereafter.

The color intensities in the cases of dimethyl-(21), methylphenyl-(44), dibenzyl-(46), methyl- $p$-nitrophenyl-(47), methyl- $p$-nitrobenzyl-(48), pentamethylene-(23), and anhydrobis (2'-hydroxyethyl)-(25) derivatives gave the peak in $5-15 \mathrm{~min}$ and then showed a relatively rapid decrease (Fig. 2c, 2d, Fig. 3b). Diethyl-(40), di-n-propyl-(41), methylbenzyl-(45), and tetramethylene-(49) guanidines produced the color, of which intensity reached to a maximum in 10-25 min, and decreased rapidly in 10-30 min, and then very slowly (Fig. 3a, 3b). Methylbenzyl-, tetramethylene- and diisopropylguanidines gave remarkably stable colors during the period from 30 to $100 \mathrm{~min}$. 


\section{Effect of $\mathrm{pH}$ on the Wave Length of $\lambda_{\max }$ of the Colored Solutions}

This effect is shown in Fig. 4. At a $\mathrm{pH}$ range of 10-13, red color was produced from 1,1-dimethylguanidine, 1,1-pentamethyleneguanidine, and creatine.

These three compounds had almost the same maximum absorption of $535 \mathrm{~m} \mu$ at these $\mathrm{pH}$ range of $10-13$.

The $\lambda_{\max }$ in the case of 1,1-pentamethyleneguanidine increased from $535 \mathrm{~m} \mu$ to $610 \mathrm{~m} \mu$ with decreasing $\mathrm{pH}$ from 10 to 9 , and became constant at $\mathrm{pH}_{a} 4$ or lower.

The colors produced from creatine and 1,1-dimethylguanidine showed maximum absorption at $\mathrm{pH} 6$ in the former and at $\mathrm{pH} 4$ in the latter.

Calculated from these curves, we obtained approximate $\mathrm{p} K_{a}$ values of $9.4,9.9$ and 9.2 in the case of creatine, 1,1-pentamethyleneguanidine and 1,1-dimethylguanidine respectively.

It was emphasized that these experiments appeared to be useful in explaining the mechanism of a guanidino structure and might be of further value in the design of specific functional group whose use may help to relate these correlations to the chemical details of the structure of the amidino compounds. 